\section{NOTE}

1 Departamento de Microbiología y Ecología, Facultad de Biología, Universitat de València, Campus de Burjassot, 46100 Valencia, Spain

2 Lehrstuhl für Mikrobiologie, Technische Universität München, Am Hochanger 4, D-85350 Freising, Germany

3 Instituto Cavanilles de Biodiversidad y Biología Evolutiva, Universitat de Valencia, Campus de Burjassot, 46100 Valencia, Spain

\title{
Vibrio agarivorans sp. nov., a novel agarolytic marine bacterium
}

\author{
M. C. Macián, ${ }^{1,2}$ W. Ludwig, ${ }^{2}$ K. H. Schleifer, ${ }^{2}$ M. J. Pujalte ${ }^{1,3}$ \\ and E. Garay ${ }^{1,3}$ \\ Author for correspondence: E. Garay. Tel: +34 96 3983143. Fax: +34 963983099. \\ e-mail: esperanza.garay@uv.es
}

\begin{abstract}
It is proposed that the new Vibrio species Vibrio agarivorans accommodates two agarolytic, halophilic, fermentative bacterial strains isolated from Mediterranean sea water. The cells were Gram-negative, oxidase-positive, polarly flagellated bacilli that fermented glucose without gas production and that produced no decarboxylases. They used a wide range of compounds as sole carbon and energy sources. The DNA G+C content was $44.8 \mathrm{~mol} \%$. Phylogenetic analysis based on complete 165 and 235 rDNA sequences revealed that the strains belong to the $\gamma$-Proteobacteria, and are specifically related to Vibrio species. Their nearest relatives were species of the Vibrio fischeri group, sharing 165 rDNA sequence similarities below $97 \%$ with the agarolytic strains. The type strain is $289^{\top}$ ( = CECT $5085^{\top}=$ DSM 13756 $)$.
\end{abstract}

Keywords: $\gamma$-Proteobacteria, marine bacteria, Vibrio agarivorans sp. nov., agarolytic activity, 16S rDNA phylogeny

The ability to hydrolyse agar, a complex polysaccharide commonly used as a solidifying agent in microbiological media, is widespread among marine bacteria. This ability is very apparent, as colonies of agarolytic bacteria grown on solid media form a pit, more or less pronounced, which sometimes progresses to a big hole. Pigmented members of the Bacteroides-Flavobacterium-Cytophaga branch (Cytophaga lytica, Cytophaga fermentans, Cytophaga latercula, Cytophaga uliginosa, Microscilla furvescens, Marinilabilia agarovorans, Persicobacter diffluens and Flameovirga aprica) and strictly aerobic proteobacteria of the genera Prosthecomicrobium (Prosthecomicrobium litoralum), Pseudoalteromonas (Pseudoalteromonas atlantica) and Pseudomonas (Pseudomonas elongata, Pseudomonas gelidicola, both incertae sedis) account for all of the currently described species showing this activity (Akawaga-Matsushita et al., 1992; Bauld et al., 1983; Nakawaga \& Yamasato, 1996; Nakawaga et al., 1997; Palleroni, 1984; Reichenbach, 1989). Recently, a thermophilic, facultatively anaerobic Gram-negative coccus, Alterococcus agarolyticus, has been described as an agarase producer (Shieh \& Jean, 1998).

The GenBank/EMBL/DDBJ accession numbers for the $16 \mathrm{~S}$ rRNA sequences of Vibrio agarivorans CECT 5085 ${ }^{\top}$ and CECT 5084 are AJ310647 and AJ310648, respectively. The accession numbers for the respective 235 rRNA sequences are AJ310649 and AJ310650.
During an annual survey of Vibrio species from marine water and bivalves on the Spanish Mediterranean coast (Arias et al., 1999), the occurrence of several large, agarolytic colonies on thiosulphate-citrate-bilesucrose (TCBS) agar plates was noted. The strains recovered from these colonies behaved as typical Vibrio species: they showed good growth on this selective medium, they were Gram-negative rods with the typical motility of polarly flagellated cells, they required $\mathrm{NaCl}$ for growth, they were fermentative in the oxidation/fermentation test, and they were oxidase-positive and produced unpigmented, agarolytic colonies on marine agar. The only reference, in the literature, to agarolytic vibrios within the genus Vibrio sensu stricto, is strain Bar, an unnamed vibrio isolated and characterized along with the strains used to describe Vibrio diazotrophicus (Guerinot \& Patriquin, 1981; Guerinot et al., 1982). The strain was included in at least two numerical taxonomic studies and could not be placed in any of the defined groups (West et al., 1985, 1986). To the best of our knowledge, this strain has not been deposited in any culture collection. Furthermore, none of the currently described Vibrio or Photobacterium spp. are recognized as agarolytic. We have investigated the taxonomic position of two of our agarolytic strains by phenotypic and phylogenetic characterization and we have concluded that they constitute a new species within the genus Vibrio, for which we propose the name Vibrio 


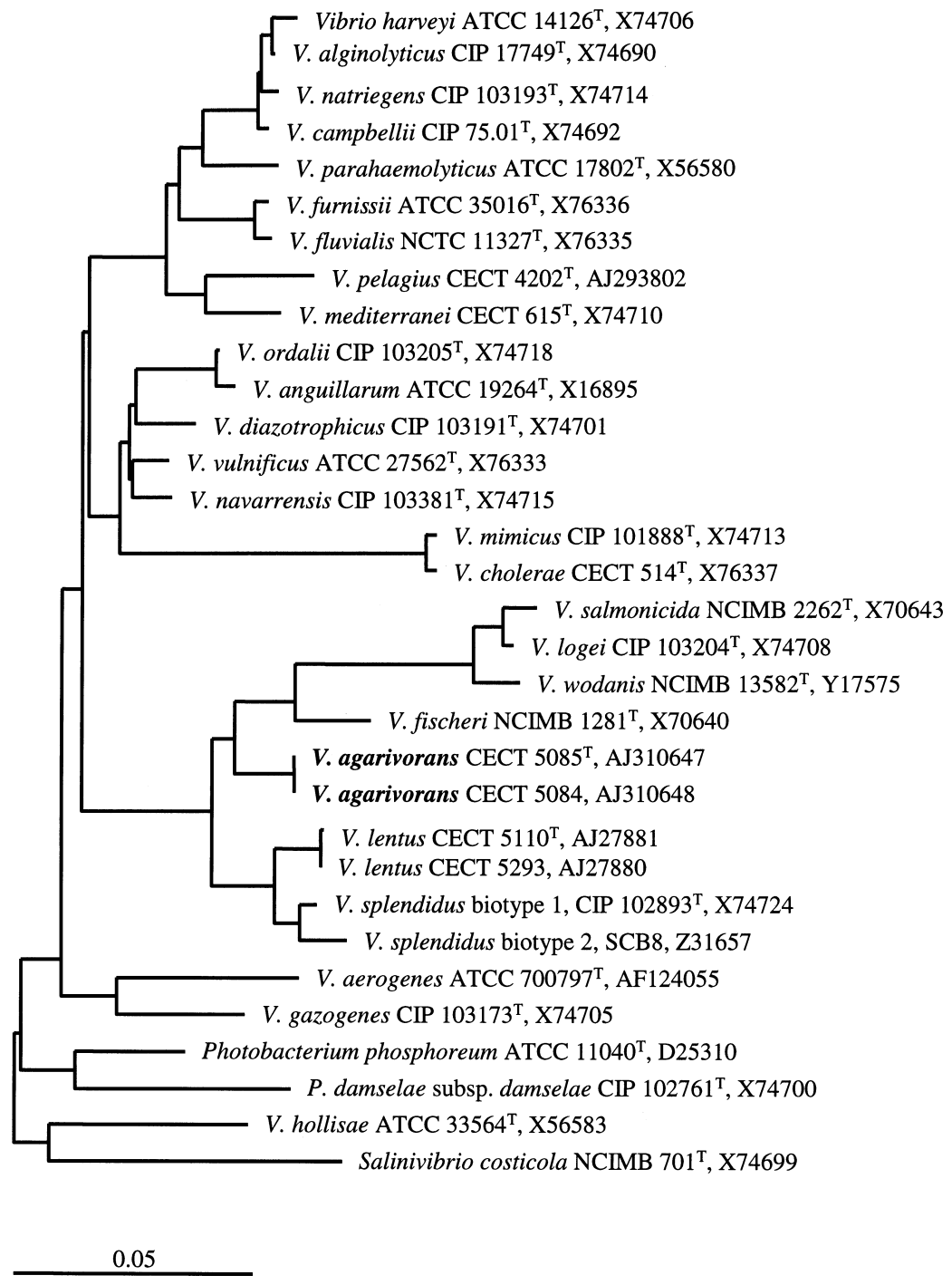

Fig. 1. Phylogenetic tree derived from maximum-parsimony analysis of the $16 \mathrm{~S}$ rRNA gene sequences of Vibrio agarivorans strains CECT $5085^{\top}$ (= DSM $13756^{\top}$ ) and CECT 5084 and other related species of the family Vibrionaceae. Bar, $5 \%$ estimated sequence divergence. Numbers near to the specific names correspond to the strain numbers and the accession numbers for the $16 \mathrm{~S}$ rDNA gene sequences.

agarivorans, and strain $289^{\mathrm{T}}\left(=\mathrm{CECT} 5085^{\mathrm{T}}=\mathrm{DSM}\right.$ $13756^{\mathrm{T}}$ ) as the type strain.

Two agarolytic sea-water strains, $289^{\mathrm{T}}$ (CECT $5085^{\mathrm{T}}$ $=$ DSM $13756^{\mathrm{T}}$ ) and 351 (CECT 5084), previously recovered during an annual study of the Spanish Mediterranean coast near Valencia, were isolated from TCBS agar (Oxoid) plates and repeatedly streaked on marine agar 2216 (Difco) plates until pure cultures were obtained. They were maintained on semi-solid marine agar stabs [marine broth 2216 (Difco) plus $0 \cdot 2 \%$ agar] at room temperature and as suspensions in marine broth $+10 \%$ glycerol at $-80{ }^{\circ} \mathrm{C}$. They were routinely grown at $25^{\circ} \mathrm{C}$, and commercial media (except for marine agar and marine broth) were supplemented with $\mathrm{NaCl}$ up to a concentration of $2 \%$ $(\mathrm{w} / \mathrm{v})$. The phenotypic profiles of both strains were determined. Most of the phenotypic tests used have been described previously (Macián et al., 2001). The nutritional spectrum of sole-carbon-source utilization was analysed in liquid media, by using Biotype ${ }^{\mathrm{R}}$ strips (bioMérieux) that allow the testing of 99 sole carbon sources and include a negative control. The strips were inoculated with $400 \mu \mathrm{l}$ per tube from a dilution of $2 \mathrm{ml}$ cell suspension (3.0 MacFarland scale) in $60 \mathrm{ml}$ basal medium (Baumann \& Baumann, 1981). Results were recorded after 2,4 and $6 \mathrm{~d}$ incubation at $25^{\circ} \mathrm{C}$. Additional carbon sources not included on the Biotype $^{\mathrm{R}}$ strips were tested on basal medium supplemented with $0.1 \%$ (L-arginine, L-glutamate, pyruvate) or $0.2 \%$ (salicin) of the compound.

The DNA $\mathrm{G}+\mathrm{C}$ content was determined from the midpoint value of the thermal denaturation profile 


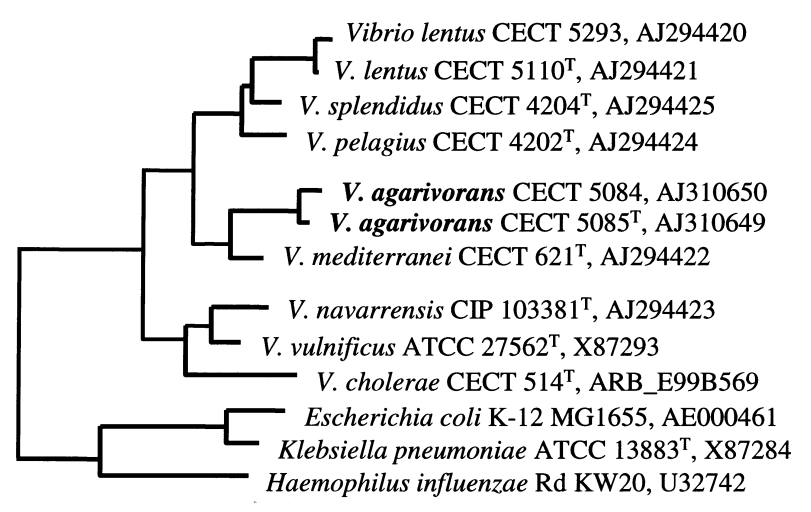

0.05

Fig. 2. Phylogenetic tree derived from distance-matrix analysis of the $23 \mathrm{~S}$ rRNA gene sequences of $V$. agarivorans strains CECT $5085^{\top}$ (= DSM 13756') and CECT 5084 and other related species of the genera Vibrio. Bar, $5 \%$ estimated sequence divergence. Numbers near to the specific names correspond to the strain numbers and the accession numbers for the 23S rDNA gene sequences.

obtained with a Gilford 2600 spectrophotometer (Mandel \& Marmur, 1968). The $\mathrm{G}+\mathrm{C}$ content was calculated by using the equation of De Ley (1970) and with Escherichia coli ATCC $11775^{\mathrm{T}}$ DNA as the reference $(\mathrm{G}+\mathrm{C}$ content $51 \mathrm{~mol} \%)$.

Isolation of genomic DNA, amplification of almost full-length $16 \mathrm{~S}$ and $23 \mathrm{~S}$ rRNA gene fragments, and sequencing of rDNA using a LICOR automated sequencer (MWG Biotech) were performed (Macián et al., 2001).

Sequences were added to the $16 \mathrm{~S}$ and $23 \mathrm{~S}$ rRNA sequence databases of the Technical University of Munich using the program package ARB (Ludwig \& Strunk, 1997). The respective ARB tools were used for automated sequence alignment. The alignment was checked by eye and corrected manually using the sequence editor ARB_EDIT. Phylogenetic analyses were performed by applying the maximum-parsimony (with the full dataset of 20000 sequences, ARB, parsimony), distance-matrix (with all available members of the $\gamma$ Proteobacteria as well as selected references from other major phylogenetic groups, ARB; Felsenstein, 1982) and maximum-likelihood methods (with known selected references from the $\gamma$-Proteobacteria, fastDNAml; Maidak et al., 1996) on different datasets varying with respect to the inclusion of variable sequence positions (Ludwig et al., 1998). The accession numbers for the $16 \mathrm{~S}$ and $23 \mathrm{~S}$ rRNA gene sequences used in the study appear in Figs 1 and 2, respectively.

The agarolytic Mediterranean sea-water bacteria are Gram-negative rods (approx. 2-4 $\mu \mathrm{m}$ long $\times 0.4$ $0.6 \mu \mathrm{m}$ wide); each rod has one polar flagellum. They grew on marine agar plates as unpigmented, nonluminous colonies that produced a shallow pit on the medium (agarolytic), and they did not swarm. They developed as agarolytic green colonies on TCBS agar (i.e. they were non-sucrose-fermenting). None of them was able to grow at 4 or $40{ }^{\circ} \mathrm{C}$, and both grew in the range $20-37^{\circ} \mathrm{C}$. They were strictly halophilic, unable to grow in $\mathrm{NaCl}$-free medium, and able to grow at $\mathrm{NaCl}$ concentrations of up to $6 \%$. They were fermentative in the oxidation/fermentation test, fermenting glucose without gas production, and gave a negative Voges-Proskauer test result. Both strains reduced nitrate to nitrite and were sensitive to the vibriostatic agent $\mathrm{O} / 129(150 \mu \mathrm{g})$. Test results for Møller's and Thornley's arginine dihydrolase, lysine and ornithine decarboxylases, indole and $\mathrm{H}_{2} \mathrm{~S}$ production were negative. The bacteria did not hydrolyse urea, gelatin, casein or starch. The nutritional profiles of both agarolytic strains $\left[289^{\mathrm{T}}\left(=\right.\right.$ CECT $5085^{\mathrm{T}}=$ DSM 13756 ${ }^{\mathrm{T}}$ ) and 351 (= CECT 5084)] were almost identical; a wide range of compounds, mainly sugars and organic acids, was utilized (see description). The strains were phenotypically different from other decarboxylase-negative Vibrio species not only because of the agarolytic ability but also on the basis of carbonsource use and the results of other biochemical tests (Table 1). Therefore, we sequenced their $16 \mathrm{~S}$ and $23 \mathrm{~S}$ rRNA genes in order to clarify their phylogenetic affiliations.

The DNA $\mathrm{G}+\mathrm{C}$ content of strain $289^{\mathrm{T}}(=\mathrm{CECT}$ $5085^{\mathrm{T}}=$ DSM $13756^{\mathrm{T}}$ ) was $44 \cdot 8 \mathrm{~mol} \%$, as determined by the thermal denaturation method, and thus was within the range for the genus Vibrio.

The almost complete sequences of the 16S rRNA and 23S rRNA genes were determined for strains $289^{\mathrm{T}}(=$ CECT $\left.5085^{\mathrm{T}}=\mathrm{DSM} 13756^{\mathrm{T}}\right)$ and $351 \quad(=\mathrm{CECT}$ 5084) and were deposited in the EBI databases under the accession numbers AJ310647 and AJ310648, respectively. Phylogenetic analysis was performed by applying the three alternative treeing methods, and the results were congruent with respect to the positioning of the new isolates. The comparative analysis of the sequences confirmed the affiliation of the strains to the family Vibrionaceae. The sequences of both strains were identical, and showed similarity of less than $97 \%$ to other Vibrio and Photobacterium species. The closest phylogenetic neighbours of our isolates were Vibrio fischeri, Vibrio logei, Vibrio salmonicida and Vibrio wodanis. The $16 \mathrm{~S}$ rDNA sequence from $V$. fischeri was the most similar, having $96.5 \%$ identical bases. $V$. logei and $V$. salmonicida showed 95.2 and $94.8 \%$ similarity, respectively, whereas the $V$. wodanis $16 \mathrm{~S}$ rDNA sequence similarity was $94 \cdot 6 \%$. According to the criteria of Stackebrandt \& Goebel (1994), these 16S sequence similarities indicate that the strains represent a different species. Fig. 1 is a phylogenetic tree for Vibrionaceae, based on the maximum-parsimony method, which includes the $16 \mathrm{~S}$ rDNA sequence data for the two strains. The phylogenetic position of these representatives is peripheral to the $V$. fischeri- $V$. logei-V. salmonicida-V. wodanis group. In several studies (Kita-Tsukamoto et al., 1993; Lunder et al., 2000; Ruimy et al., 1994; Sawabe et al., 1998; Shieh et 
Table 1. Characteristics useful for distinguishing Vibrio agarivorans sp. nov. from its closest phylogenetic neighbours and other amino-acid-negative Vibrio spp.

The data shown are from the following references: Baumann et al. (1984), Benediktsdóttir et al. (2000), Borrego et al. (1996), Fidopiastis et al. (1999), Guerinot \& Patriquin (1981), Guerinot et al. (1982), Ishimaru et al. (1995, 1996), Macián et al. (2001) and Sawabe et al. (1998). The numbers represent the following species/strains of the genus Vibrio: 1, V. agarivorans; 2 , V. diazotrophicus; 3, strain Bar; 4, V. fischeri; 5, V. logei; 6, V. salmonicida; 7, V. wodanis; 8, V. natriegens; 9, V. pelagius biotype 1; $10, V$. pelagius biotype $2 ; 11, V$. ordallii; $12, V$. gazogenes; $13, V$. ichtyoenteri; $14, V$. splendidus biotype $2 ; 15$, V. nigripulchritudo; 16, V. penaeicida; 17, V. navarrensis; 18, V. tapetis; 19, V. halioticoli; 20, V. lentus. Test results: +, positive; -, negative; v, variable response; ND, no data available.

\begin{tabular}{|c|c|c|c|c|c|c|c|c|c|c|c|c|c|c|c|c|c|c|c|c|}
\hline Test & 1 & 2 & 3 & 4 & 5 & 6 & 7 & 8 & 9 & 10 & 11 & 12 & 13 & 14 & 15 & 16 & 17 & 18 & 19 & 20 \\
\hline Luminescence & - & - & - & + & + & $+^{*}$ & - & - & - & - & - & - & - & - & - & - & - & - & - & - \\
\hline Pigment & - & - & - & Yellow & Yellow & - & Yellow & - & - & - & - & Red & - & - & Black & - & - & - & - & - \\
\hline Thornley's arginine dihydrolase & - & $\mathrm{v}$ & - & - & - & - & ND & - & - & - & - & - & - & - & - & ND & - & - & - & + \\
\hline Lysine decarboxylase & - & - & - & + & + & - & - & - & - & - & - & - & - & - & - & - & - & - & - & - \\
\hline Indole & - & + & - & - & - & - & $\mathrm{v}$ & - & - & + & - & - & - & + & + & $\mathrm{v}$ & + & + & + & $\mathrm{v}$ \\
\hline Acid from sucrose & - & + & + & - & - & - & $\mathrm{v}$ & + & + & + & + & + & $\mathrm{v}$ & + & - & - & + & - & - & - \\
\hline Growth at $4{ }^{\circ} \mathrm{C}$ & - & + & + & - & + & + & + & + & $\mathrm{v}$ & $\mathrm{v}$ & - & - & - & - & - & - & - & + & - & v \\
\hline Growth at $40^{\circ} \mathrm{C}$ & - & $\mathrm{v}$ & + & - & - & - & - & + & - & - & - & + & - & - & - & - & + & - & - & - \\
\hline \multicolumn{21}{|l|}{ Hydrolysis of } \\
\hline Agar & + & - & + & - & - & - & - & - & - & - & - & - & - & - & - & - & - & - & - & - \\
\hline Starch & $\mathrm{v}$ & + & + & - & - & ND & + & $\mathrm{v}$ & - & - & - & + & - & + & + & $\mathrm{V}$ & + & + & - & + \\
\hline \multicolumn{21}{|l|}{ Use of: } \\
\hline D-Ribose & - & + & ND & + & $\mathrm{v}$ & v & ND & + & + & + & + & + & ND & + & - & ND & + & ND & ND & v \\
\hline D-Xylose & + & + & ND & - & - & - & ND & - & - & - & - & + & - & - & - & - & - & ND & + & - \\
\hline L-Arabinose & - & + & ND & - & - & - & ND & + & - & - & - & + & ND & - & - & ND & - & - & - & - \\
\hline Mannose & - & - & + & + & $\mathrm{v}$ & $\mathrm{v}$ & + & $\mathrm{v}$ & V & + & - & + & ND & - & + & ND & ND & + & $\mathrm{v}$ & + \\
\hline Cellobiose & + & + & + & + & + & - & ND & $\mathrm{v}$ & - & - & - & + & - & $\mathrm{v}$ & + & + & $\mathrm{V}$ & - & $\mathrm{v}$ & + \\
\hline Sucrose & - & + & + & - & - & - & ND & + & + & - & + & + & $\mathrm{v}$ & - & - & - & + & - & - & - \\
\hline Lactose & + & + & + & - & - & - & ND & - & $\mathrm{V}$ & $\mathrm{v}$ & - & - & ND & - & + & ND & - & - & - & - \\
\hline Melibiose & + & - & ND & - & - & - & ND & $\mathrm{v}$ & - & - & - & ND & ND & - & + & ND & - & - & - & - \\
\hline D-Gluconate & $\mathrm{v}$ & + & $\mathrm{ND}$ & - & + & + & ND & + & + & + & - & - & $\mathrm{V}$ & - & $\mathrm{v}$ & $\mathrm{V}$ & + & - & - & $\mathrm{v}$ \\
\hline D-Glucuronate & - & + & ND & - & - & ND & ND & $\mathrm{v}$ & - & - & - & - & - & - & + & - & - & - & - & $\mathrm{v}$ \\
\hline Sorbitol & - & - & - & - & - & - & ND & - & - & - & - & + & ND & - & + & ND & - & - & - & - \\
\hline 2-Ketoglutarate & - & + & ND & - & - & $\mathrm{v}$ & ND & + & - & - & - & + & ND & + & + & ND & $\mathrm{v}$ & - & - & $\mathrm{v}$ \\
\hline Putrescine & - & + & ND & - & - & $\mathrm{ND}$ & ND & + & + & + & - & - & - & - & - & - & - & - & - & - \\
\hline L-Arginine & - & + & + & - & - & ND & ND & + & + & + & ND & - & ND & - & - & ND & ND & ND & ND & - \\
\hline
\end{tabular}

* From Fidopiastis et al. (1999).

al., 2000; Yumoto et al., 1999), this group remains clearly isolated from the groups containing the Photobacterium spp., the Vibrio anguillarum-Vibrio ordaliiVibrio diazotrophicus-Vibrio vulnificus-Vibrio navarrensis clade, and the so-called 'core' of marine Vibrio species (Vibrio parahaemolyticus, Vibrio alginolyticus, Vibrio harveyi, Vibrio campbellii, Vibrio natriegens).

The almost complete sequence of the $23 \mathrm{~S}$ rRNA gene was also determined for both strains; these sequences were deposited at the EBI databases under the accession numbers AJ310649 and AJ310650. The distance-matrix analysis yielded the dendrogram shown in Fig. 2. The currently available number of complete 23S rDNA sequences of Vibrio spp. (seven out of 44 validly described species) is still very low. The 23S rDNA sequences of Vibrio lentus, Vibrio mediterranei, V. navarrensis, Vibrio pelagius and Vibrio splendidus were determined by our group in a previous study (Macián et al., 2001). The relevance of using $23 \mathrm{~S}$ rDNA sequences lies in the higher number of informative positions they possess because of the larger length of the molecule. Moreover, 23S rRNA sequences, as well as 16S rRNA sequences, can be used as evolutionary markers, and confirm the results of the phylogenetic studies based on the small-subunit RNA. In the present study, the phylogenetic organization of the available Vibrio spp. 23S rDNA sequences (Fig. 2) is congruent with the one based on $16 \mathrm{~S}$ rDNA sequences (Fig. 1). The value for $23 \mathrm{~S}$ rDNA sequence similarity between strains $289^{\mathrm{T}}\left(=\right.$ CECT $5085^{\mathrm{T}}=$ DSM $\left.13756^{\mathrm{T}}\right)$ and 351 (= CECT 5084) was $99.6 \%$, whereas the levels of similarity between the sequences of these two strains and those of other Vibrio species varied between 92.9 and $96.8 \%$ (with $V$. navarrensis and $V$. mediterranei, respectively).

Strain Bar (isolated from sea urchin; Guerinot \& Patriquin, 1981), the only strain within the genus Vibrio described as agarolytic, was not available in any culture collection and therefore could not be included in the sequence study. This strain was reported to be able to grow at 4 and $42{ }^{\circ} \mathrm{C}$ as well as on L-arginine and salicin (but not succinate) as sole carbon sources, whereas the responses of our agarolytic sea-water strains for these five tests were just the opposite. Phenotypic characterization showed that strains $289^{\mathrm{T}}$ $\left(=\mathrm{CECT} 5085^{\mathrm{T}}=\mathrm{DSM} 13756^{\mathrm{T}}\right)$ and $351(=\mathrm{CECT}$ 5084) share properties common in members of the genus Vibrio, according to Baumann et al. (1984), but at the same time they can be easily differentiated from 
other decarboxylase-negative or phylogenetically related Vibrio species (Table 1).

On the basis of phenotypic characterization and rRNA sequence analysis it can be concluded that the two agarolytic strains studied are different from any Vibrio and Photobacterium species described so far. Although there is a high probability that both strains do pertain to the same species, in view of the nearly identical phenotype and $16 \mathrm{~S}$ and $23 \mathrm{~S}$ rRNA sequences, further DNA-DNA reassociation experiments will definitively confirm the ascription of strain 351 (= CECT 5084) to the proposed new species, according to the criteria established for genospecies recognition (Wayne et al., 1987). The name $V$. agarivorans sp. nov. is proposed for this species, and strain $289^{\mathrm{T}}\left(=\right.$ CECT $5085^{\mathrm{T}}=$ DSM $\left.13756^{\mathrm{T}}\right)$ is proposed as the type strain.

Further studies involving genetic and phylogenetic characterization of the rest of agarolytic strains recovered in the original study are in progress (Arias et al., 1999).

\section{Description of Vibrio agarivorans sp. nov.}

Vibrio agarivorans (a.ga.ri.vo'rans. Malayan n. agar agar; N.L. n. agarum, - $i$ agar; M.L. v. vorare to devour; N.L. part. adj. agarivorans agar-eating).

Gram-negative rods, approximately $2-4 \mu \mathrm{m}$ long $\times$ $0.4-0.6 \mu \mathrm{m}$ wide, facultatively anaerobic, motile by one polar flagellum. Colonies are regular in shape and unpigmented. On TCBS agar, they grow as green colonies. Glucose metabolism is fermentative without gas production. Tests for catalase, oxidase and nitrate reduction to nitrite are positive. No growth occurs without the addition of $\mathrm{NaCl}$ to the culture medium. Growth occurs between 20 and $37^{\circ} \mathrm{C}$. Not luminescent. Indole, $\mathrm{H}_{2} \mathrm{~S}$ production from thiosulphate, Møller's and Thornley's arginine dihydrolase, and ornithine and lysine decarboxylase test results are negative. Hydrolyses agar. Utilizes the following substrates as sole carbon and energy sources: D-glucose, D-fructose, D-galactose, D-melibiose, maltotriose, maltose, $\alpha$-lactose, 1- $O$-methyl $\beta$-galactopyranoside, $1-O$-methyl $\alpha$-galactopyranoside, D-cellobiose, Dxylose, D-mannitol, mucate, L-malate, 2-keto-Dgluconate, $\mathrm{N}$-acetylglucosamine, caprate, succinate, fumarate, DL-glycerate, D-glucosamine, L-glutamate, L-serine and L-aspartate. None of the strains utilizes the following substrates: D-trehalose, D-mannose, Lsorbose, sucrose, D-raffinose, lactulose, $\beta$-gentibiose, 1-O-methyl $\beta$-D-glucopyranoside, D-ribose, L-arabinose, palatinose, L-rhamnose, L-fucose, D-melezitose, D-arabitol, L-arabitol, xylitol, dulcitol, D-tagatose, glycerol, myo-inositol, maltitol, D-turanose, D-sorbitol, adonitol, hydroxyquinoline- $\beta$-glucuronide, Dlyxose, $i$-erythritol, 1- $O$-methyl $\alpha$-D-glucopyranoside, 3-O-methyl D-glucopyranose, D-saccharate, L-tartrate, D-tartrate, m-tartrate, D-malate, cis-aconitate, transaconitate, tricarballylate, citrate, D-glucuronate, Dgalacturonate, 5-keto-D-gluconate, L-tryptophan, phenylacetate, protocatechuate, $p$-hydroxybenzoate, quinate, gentisate, $m$-hydroxybenzoate, benzoate, 3-phenylpropionate, m-coumarate, trigonelline, betain, putrescine, DL- $\alpha$-aminobutyrate, histamine, DL-lactate, caprylate, L-histidine, glutarate, DL- $\alpha$ aminovalerate, ethanolamine, tryptamine, itaconate, DL- $\beta$-hydroxybutyrate, D-alanine, malonate, 2 oxoglutarate, L-arginine and salicin. Isolated from sea water at the Mediterranean coast of Valencia (Spain). Type strain $289^{\mathrm{T}}$ has been deposited at the Colección Española de Cultivos Tipo (Valencia, Spain) as strain CECT $5085^{\mathrm{T}}$, and at the Deutsche Sammlung von Mikroorganismen und Zellkulturen as DSM $13756^{\mathrm{T}}$. The $\mathrm{G}+\mathrm{C}$ content of DNA of the type strain is $44.8 \mathrm{~mol} \%$. Strain 351 has been also deposited at both collections as CECT 5084 and DSM 13755, respectively.

Characteristics of the type strain of Vibrio agarivorans sp. nov. The type strain of $V$. agarivorans is $289^{\mathrm{T}}$, isolated in Spain from Mediterranean sea water. In addition to the characteristics that define the species, it has the following features: it utilizes aesculin and L-proline as sole carbon and energy sources, but not D-gluconate, L-alanine, L-tyrosine or pyruvate.

\section{Acknowledgements}

This work was partially supported by the 'Deutsche Forshungsgemeinschaft'.

\section{References}

Akagawa-Matsushita, M., Matsuo, M., Koga, Y. \& Yamasato, K. (1992). Alteromonas atlantica sp. nov. and Alteromonas carrageenovora sp. nov., bacteria that decompose algal polysaccharides. Int J Syst Bacteriol 42, 621-627.

Arias, C. R., Macián, M. C., Aznar, R., Garay, E. \& Pujalte, M. J. (1999). Low incidence of Vibrio vulnificus among Vibrio isolates from seawater and shellfish of the Western Mediterranean coast. J Appl Microbiol 86, 125-134.

Bauld, J., Bigford, R. \& Staley, J. T. (1983). Prosthecomicrobium litoralum, a new species from marine habitats. Int $J$ Syst Bacteriol 33, 613-617.

Baumann, P. \& Baumann, L. (1981). The marine gram-negative eubacteria: genera Photobacterium, Beneckea, Alteromonas, Pseudomonas and Alcaligenes. In The Prokaryotes, vol. II, pp. 1302-1331. Edited by M. P. Starr, H. Stolp, H. G. Trüper, A. Balows \& H. Schleger. Berlin: Springer.

Baumann, P., Furniss, A. L. \& Lee, J. V. (1984). Genus I. Vibrio Pacini 1854. In Bergey's Manual of Systematic Bacteriology, vol. 1, pp. 518-550. Edited by N. R. Krieg \& J. G. Holt. Baltimore, MD: Williams \& Wilkins.

Benediktsdóttir, E., Verdonck, L., Spröer, C., Helgason, S. \& Swings, J. (2000). Characterization of Vibrio viscosus and Vibrio wodanis isolated at different geographical locations: a proposal for reclassification of Vibrio viscosus as Moritella viscosa comb. nov. Int J Syst Evol Microbiol 50, 479-488.

Borrego, J. J., Castro, D., Luque, A., Paillard, C., Maes, P., García, M. T. \& Ventosa, A. (1996). Vibrio tapetis sp. nov., the causative agent of the brown ring disease affecting cultured clams. Int $J$ Syst Bacteriol 46, 480-484. 
De Ley, J. (1970). Re-examination of the association between melting point, buoyant density, and chemical base composition of deoxyribonucleic acid. J Bacteriol 101, 738-754.

Felsenstein, J. (1982). Numerical methods for inferring phylogenetic trees. Quart Rev Biol 57, 379-404.

Fidopiastis, P. M., Sørum, H. \& Ruby, E. G. (1999). Cryptic luminescence in the cold-water fish pathogen Vibrio salmonicida. Arch Microbiol 171, 205-209.

Guerinot, M. L. \& Patriquin, D. G. (1981). $\mathrm{N}_{2}$-fixing vibrios isolated from the gastrointestinal tract of sea urchins. Can $J$ Microbiol 27, 311-317.

Guerinot, M. L., West, P. A., Lee, J. V. \& Colwell, R. R. (1982). Vibrio diazotrophicus sp. nov., a marine nitrogen-fixing bacterium. Int J Syst Bacteriol 32, 350-357.

Ishimaru, K., Akagawa-Matsushita, M. \& Muroga, K. (1995). Vibrio penaeicida sp. nov., a pathogen of kuruma prawns (Penaeus japonicus). Int J Syst Bacteriol 45, 134-138.

Ishimaru, K., Akagawa-Matsushita, M. \& Muroga, K. (1996). Vibrio ichthyoenteri sp. nov., a pathogen of Japanese flounder (Paralichthys olivaceus) larvae. Int J Syst Bacteriol 46, 155-159.

Kita-Tsukamoto, K., Oyaizu, H., Nanba, K. \& Simidu, U. (1993). Phylogenetic relationships of marine bacteria, mainly members of the family Vibrionaceae, determined on the basis of $16 \mathrm{~S}$ rRNA sequences. Int $J$ Syst Bacteriol 43, 8-19.

Ludwig, W. \& Strunk, O. (1997). ARB : a software environment for sequence data. http://www.mikro.biologie.tu-muenchen.de/ pub/ARB/documentation/ARB.ps.

Ludwig, W., Strunk, O., Klugbauer, S., Klugbauer, N., Weizenegger, M., Neumaier, J., Bachleitner, M. \& Schleifer, K.-H. (1998). Bacterial phylogeny based on comparative sequence analysis. Electrophoresis 19, 554-568.

Lunder, T., Sørum, H., Holstad, G., Steigerwalt, A. G., Mowinckel, P. \& Brenner, D. J. (2000). Phenotypic and genotypic characterization of Vibrio viscosus sp. nov. and Vibrio wodanis sp. nov. isolated from Atlantic salmon (Salmo salar) with 'winter ulcer'. Int J Syst Evol Microbiol 50, 427-450.

Macián, M. C., Ludwig, W., Aznar, R., Grimont, P. A. D., Schleifer, K.-H., Garay, E. \& Pujalte, M. J. (2001). Vibrio lentus sp. nov., isolated from Mediterranean oysters. Int J Syst Evol Microbiol 51, 1449-1456.

Maidak, B. L., Olsen, G. J., Larsen, N., Overbeek, R., McCaughey, M. J. \& Woese, C. R. (1996). The ribosomal database project. Nucleic Acids Res 24, 82-85.

Mandel, M. \& Marmur, J. (1968). Use of ultraviolet absorbancetemperature profile for determining the guanosine plus cytosine content of DNA. In Methods in Enzymology, vol. 12B, pp. 195-206. Edited by L. Grosman \& K. Moldave. New York: Academic Press.

Nakagawa, Y. \& Yamasato, K. (1996). Emendation of the genus Cytophaga and transfer of Cytophaga agarovorans and Cytophaga salmonicolor to Marinilabilia gen. nov.: phylogenetic analysis of the Flavobacterium-Cytophaga complex. Int J Syst Bacteriol 46, 599-603.

Nakagawa, Y., Hamana, K., Sakane, T. \& Yamasato, K. (1997). Reclassification of Cytophaga aprica (Lewin 1969) Reichenbach 1989 in Flammeovirga gen. nov. as Flammeovirga aprica comb. nov. and of Cytophaga diffluens (ex Stanier 1940; emend. Lewin 1969) Reichenbach 1989 in Persicobacter gen. nov. as Persicobacter diffluens comb. nov. Int J Syst Bacteriol 47, 220-223.

Palleroni, N. J. (1984). Genus I. Pseudomonas Migula 1894, $237^{\mathrm{AL}}$ (nom. cons. Opin. 5, Jud. Comm. 1952, 237). In Bergey's Manual of Systematic Bacteriology, vol. 1, pp. 141-199. Edited by N. R. Krieg \& J. G. Holt. Baltimore, MD: Williams \& Wilkins

Reichenbach, H. (1989). Order Cytophagales Winogradsky 1929 , $557^{\mathrm{AL}}$, emend. In Bergey's Manual of Systematic Bacteriology, vol. 3, pp. 2011-2077. Edited by J. T. Staley, M. P. Bryant, N. Pfennig \& J. G. Holt. Baltimore, MD: Williams \& Wilkins.

Ruimy, R., Breittmayer, V., Elbaze, P., Lafay, B., Boussemart, O., Gauthier, M. \& Christen, R. (1994). Phylogenetic analysis and assessment of the genera Vibrio, Photobacterium, Aeromonas and Plesiomonas deduced from small-subunit rRNA sequences. Int J Syst Bacteriol 44, 416-426.

Sawabe, T., Sugimura, I., Ohtsuka, M., Nakano, K., Tajima, K., Ezura, Y. \& Christen, R. (1998). Vibrio halioticoli sp. nov., a nonmotile alginolytic marine bacterium isolated from the gut of the abalone Haliotis discus hannai. Int J Syst Bacteriol 48, 573-580.

Shieh, W. Y. \& Jean, W. D. (1998). Alterococcus agarolyticus, gen. nov., sp. nov., a halophilic thermophilic bacterium capable of agar degradation. Can J Microbiol 44, 637-645.

Shieh, W. Y., Chen, A.-L. \& Chiu, H.-H. (2000). Vibrio aerogenes sp. nov., a facultatively anaerobic marine bacterium that ferments glucose with gas production. Int J Syst Evol Microbiol 50, 321-329.

Stackebrandt, E. \& Goebel, B. M. (1994). Taxonomic note: a place for DNA-DNA reassociation and 16S rRNA sequence analysis in the present species definition in bacteriology. Int $J$ Syst Bacteriol 44, 846-849.

Wayne, L. G., Brenner, D. J., Colwell, R. R. \& 9 other authors. (1987). International Committee on Systematic Bacteriology. Report of the ad hoc committee on reconciliation of approaches to bacterial systematics. Int J Syst Bacteriol 37, 463-464.

West, P. A., Brayton, P. R., Twilley, R. R., Bryant, T. N. \& Colwell, R. R. (1985). Numerical taxonomy of nitrogen-fixing 'decarboxylase-negative' Vibrio species isolated from aquatic environments. Int J Syst Bacteriol 35, 198-205.

West, P. A., Brayton, P. R., Bryant, T. N. \& Colwell, R. R. (1986). Numerical taxonomy of vibrios isolated from aquatic environments. Int J Syst Bacteriol 36, 531-543.

Yumoto, I., Iwata, H., Sawabe, T., Ueno, K., Ichise, N., Matsuyama, H., Okuyama, H. \& Kawasaki, K. (1999). Characterization of a facultatively psychrophilic bacterium, Vibrio rumoiensis sp. nov., that exhibits high catalase activity. Appl Environ Microbiol 65, 67-72. 